\section{CENTENARY OF THE SMITHSONIAN INSTITUTION}

$\mathrm{T}$

THE Smithsonian Institution was established on August 10,1846, in accordance with the terms of the will of James Sndthson, a wealthy Englishman interested in science. At his death, seventeen years before, he had loft his fortune of approximately $550 ; 000$ dollars

Washington the United States to set up in institution "for the increase and diffusion of khowledge among men".

The estaflishment thus became the first of the great englowed scientific organisations which have been in a major degree responsible for the great cultural and material progress of the last century. federal appropriations - notably the National Museum, the Bureau of American Ethnology, the Astrophysical Observatory, the International Exchange Service, the National Zoological Park, the National Collection of Fine Arts, and the Freer Gallery of Art. The National Gallery of Art also is a bureau of the Institution, but is administered by a separate Board of Trustees. In addition, the Institution carries out independent pioneer work with its own funds.

The Smithsonian Institution has become known to the general public for its enormous collections, many of which are on eontinuous exhibition, ranging from dinosaurs to aeroplanes and from famous paintings to the dresses of Presidents' wives. The great value of the collections, however, is in their service to science. Here it is possible for experts to check the identity of

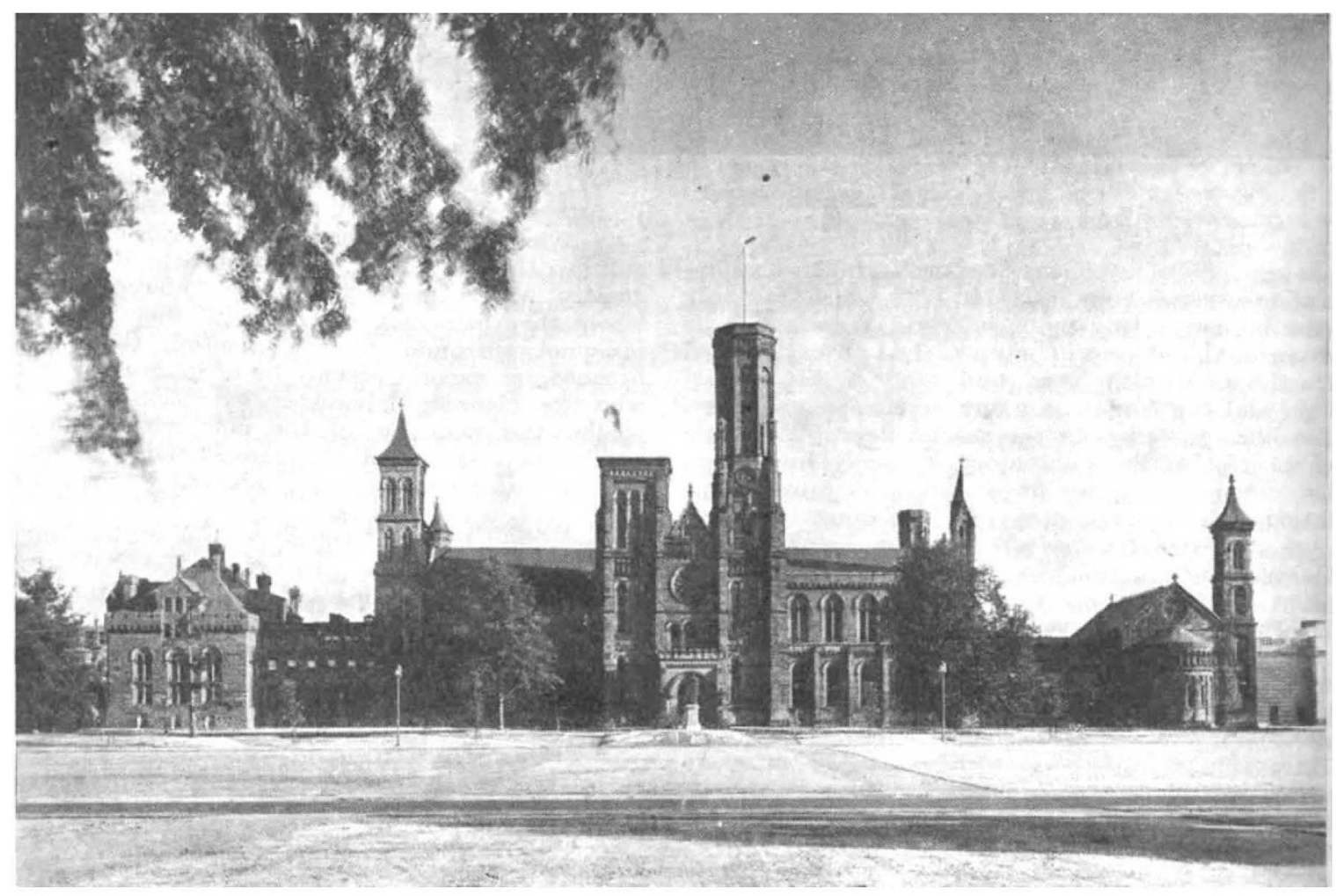

THE SMITHSONIAN INSTITUTION

Among all such institutions everywhere the Smithsonian has had a unique position. It has been intimately associated with the National Government, yet at the same time it has had the freedom of action associated with private foundations. It has been from the beginning a torch-bearer of scientific research in the United States. At the time of its establishment the pursuit of science was largely that of interested individuals, dependent on their own resources, which never were adequate for the long-term, basic, laborious researches essential for a true understanding of Nature.

Owing to its close association with the Government, the Smithsonian has enjoyed exceptional facilities from the beginning. To-day it administers and directs the research activities of several scientific and cultural bureaux, most of which are supported by direct nearly any animal, plant, or mineral found in the world, either extinct or extant. These collections now include nearly twenty million items-a number that increases constantly at a rate of more than a quarter of a million a year. The greatest number of items is in the field of natural history. In the beginning the Smithsonian had essentially a scientifically unexplored continent as a field for its collectors and explorers. Year after year it has sent out collecting expeditions to all parts of the world, including, of course, all sections of the United States.

The interest of Smithsonian explorers has been to obtain and preserve as complete as possible a picture of all Nature in its infinite manifestations. The Institution maintains departments in all the major branches of natural history, from entomology to physical anthropology. 
The Smithsonian was the pioneer, and ever since has been among the leaders, in all scientific research dealing with the aboriginal peoples of the Americas. These now are conducted largely by a Governmentsupported division-the Bureau of American Ethnology. At the time this work started just after the American Civil War, scientific interest in the remains, languages, and ways of primitive peoples was in its infancy. Thus the work of the Bureau, with the exceptional facilities at its disposal, has been fundamental in the development of the entire science of ethnology, and its publications are considered basic documents of this science all over the world.

Samuel P. Langley was a pioneer in the development of aviation. His steam-driven model "aerodromes" flew without a pilot repeatedly for distances of more than half a mile as early as 1896. The Smithsonian collection of aeroplanes which have played notable parts in aviation history is probably the largest in the world.

Study of precise solar-terrestrial relationships has been a major Smithsonian activity for many years. This has involved especially very exact measurements of periodic variations in the sun's radiation and the mechanism of photosynthesis in green plants. Observations now are carried out daily at three observatories on high mountain-tops in California,

New Mexico, and Chile.

This work has required development of measuring instruments of almost incredible delicacy-one of them capable of measuring a change of heat as small as one-millionth of a degree.

In the United States originated such devices as the telegraph and telephone, the cotton gin, the sewing machine, the harvester, and scores of others. The original machines are objects of historic interest to the American people. The Smithsonian has the responsibility for collecting and preserving these historic prototypes. The Museum collections of the Smithsonian are visited by more than two million persons each year.

The American history collections are especially rich. Perhaps the best-known items are dresses of ladies of the White House from Martha Washington to Mrs. Franklin D. Roosevelt.

In carrying on "the diffusion of knowledge", the Institution has published more than 7,500 individual books and pamphlets in nearly every field of science, most of them based on original research. It also maintains a large library of scientific books and pamphlets, covering all the fields in which it is chiefly engaged.

In the field of art the Smithsonian has three bureaux, as follows :

The National Gallery of Art, given to the nation by the late Andrew W. Mellon and containing his own collections, as well as other famous collections. The National Gallery is administered by a separate Board of Trustees.

The Freer Gallery of Art, one of the most important collections of Oriental art in America, a gift to the people of the United States from the late Charles L. Freer of Detroit.

The National Collection of Fine Arts, a generalized collection which is temporarily housed in the U.S. National Museum, pending authorization of a new building.

\section{A FREQUENCY ANALYSER USED IN THE STUDY OF OCEAN WAVES $30 \%$}

By N. F. BARBER, F. URSELL, J. DARBYSHIRE M. J. TUCKER

Admiralty Research Laboratory, Teddington

A WAVE-ANAIY War was developed at the A Admiral 5 Pesearch Laboratory, Teddington, in 1944 in ord e to analyse ocean waves and swell and ship r ofement. The apparatus has been in regular use Nince February 1945 drawing the frequency spectra of records of wave motion taken near Lands End.

These records of water pressure or depth are taken continuously for 20 minutes, and appear in the form of a black trace of variable width on white photographic paper. Fig. I shows a short length of record. On one side of the record is a time trace

Fig. 1. A WAVE-PRESSURE RECORD

consisting of a black strip interrupted every 20 sec. By attaching the paper record to the outside of the rotating wheel in Fig. 2, photocells, illuminated by the reflected light from a narrow light beam falling on the record, give a fluctuating electrical output which is a repetition at high speed of the fluctuating trace on the record.

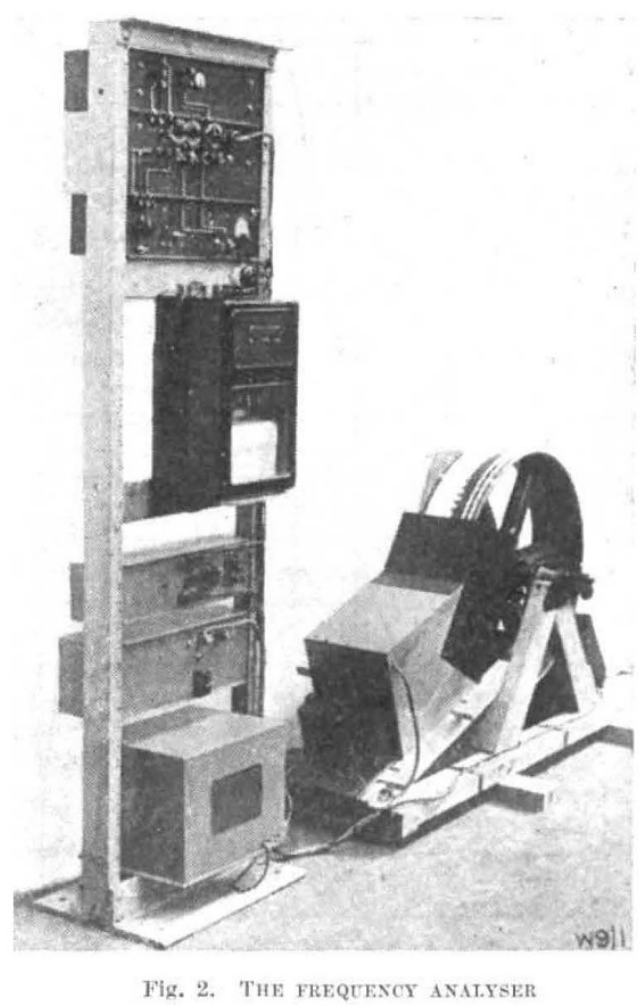

